\title{
Measurement of rail vehicles exhaust emissions
}

ARTICLE INFO

Received: 6 August 2021

Revised: 20 September 2021

Accepted: 23 September 2021

Available online: 24 September 2021
The basic problem in terms of measuring exhaust emissions is the approval tests of traction vehicles, which are carried out on engine dynamometers. Therefore, it is impossible to obtain reliable results concerning their actual impact on the natural environment. It is therefore advisable to carry out the tests in real operation conditions, as is the case for road vehicles for which RDE (Real Driving Emissions) tests are carried out. The latest Stage $V$ emission standards push for the introduction of this type of test, but no limit values for toxic exhaust gases have been established and no test guidelines have been defined for assessing actual emissions. This article describes the issues related to the legislative guidelines for non-road vehicles in force in Europe, as well as the measurement tools used, such as mobile equipment for measuring emissions of PEMS (Portable Emissions Measurement Systems) and newly developed emission gates. Additionally, the paper presents examples of locomotive exhaust emission tests in real operating conditions. The aim of the measurements was to assess the emission of toxic compounds against the relevant standards. The subject of the research was a diesel locomotive type T448.P equipped with a modernized internal combustion engine.

Key words: exhaust emission, rail vehicles, RDE, PEMS, NRMM

This is an open access article under the CC BY license (http://creativecommons.org/licenses/BY/4.0/)

\section{Introduction}

Despite efforts to electrify vehicles used in road and rail traffic, vehicles with internal combustion engines still constitute a significant part of rail vehicles used in Poland (Fig. 1). The planned modernization works and purchases of new vehicles announced by Polish railway operators indicate that the future of vehicles with internal combustion engines on Polish tracks seems to be safe for the next several years or even a decade. Freight carriers have planned investments in 167 locomotives with the financial value of approximately PLN 930 million for the years 2017-2023 [19]. This situation may be influenced by the degree of electrification of the polish railway network, which has changed slightly over the years and in the years (2003-2018) increased from $59.8 \%$ to $61.8 \%$ [11-14]. This means that in $2018,7341 \mathrm{~km}$ of tracks in Poland were not available for electric rolling stock.

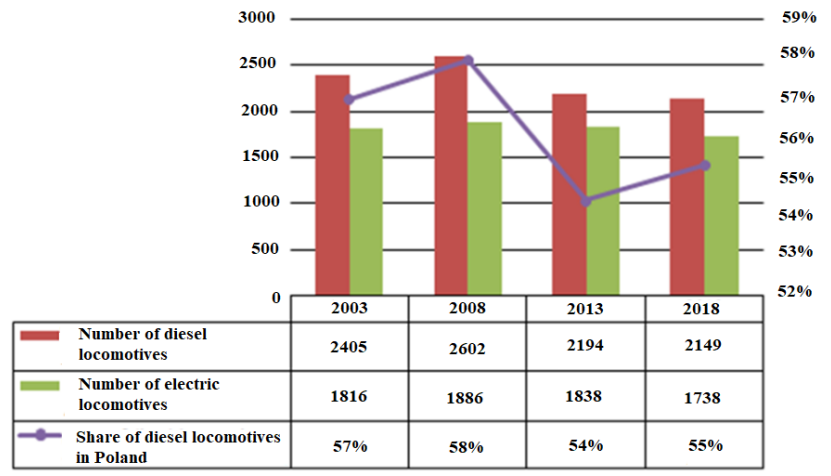

Fig. 1. The structure of the rolling stock in Poland in 2003-2018 [11-14]

\section{Exhaust emission standards for rail vehicles used in Poland}

The development of measuring technology and research on the harmful effects of substances emitted in exhaust gases meant that several decades ago, increasing awareness began to appear regarding the risks associated with the emissions from internal combustion engines. As a consequence, exhaust emission standards for rail vehicle engines were developed and put into place. The ORE B13 report is the oldest form of formal recording of exhaust emission limits for vehicles used in Poland. Based on this document a twenty-nine-phase test was carried out (Fig. 2), from which four evenly distributed operating points were selected for the calculations.

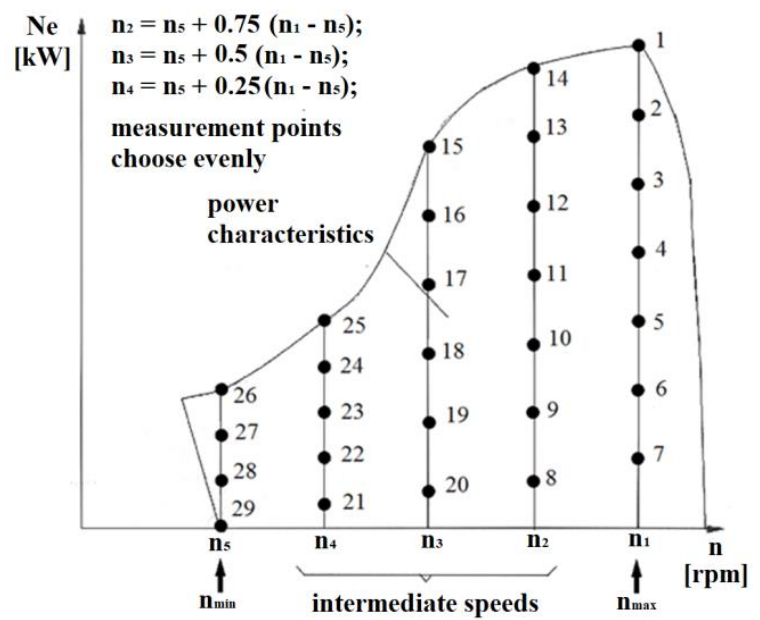

Fig. 2. The ORE B13 test measurement points [6]

Along with the above-mentioned test, emission limits for such compounds as: $\mathrm{CO}, \mathrm{HC}$ and $\mathrm{NO}_{\mathrm{x}}$ were introduced (Table 1). The standards for off-road vehicles provide the maximum value of the specific emissions for each exhaust component, i.e. expressed in the mass of substance emitted in the process of generating a unit of work. The most recent version, introduced in 1997, assumed a fourfold reduction 
in carbon monoxide emissions, a fivefold reduction in hydrocarbon emissions and a twofold reduction in nitrogen oxides emissions compared to the first stage. At the same time, the opacity of the exhaust gases was to remain at the same level all the time.

Table 1. Exhaust emission limit value according to ORE B13 [1]

\begin{tabular}{|l|c|c|c|c|}
\hline \multirow{2}{*}{ Applicable } & $\mathrm{CO}$ & $\mathrm{HC}$ & $\mathrm{NO}_{\mathrm{x}}$ & Opacity k \\
\cline { 2 - 5 } & \multicolumn{3}{|c|}{$\mathrm{g} / \mathrm{kWh}$} & $\mathrm{m}^{-1}$ \\
\hline Until 31.12.1981 & 12 & 4.0 & 24 & $1.6-2.5$ \\
\hline Since 01.01.1982 & 8 & 2.4 & 20 & $1.6-2.5$ \\
\hline Since 01.02.1991 & 4 & 1.6 & 16 & $1.6-2.5$ \\
\hline Since 01.02.1997 & 3 & 0.8 & 12 & $1.6-2.5$ \\
\hline
\end{tabular}

Poland's accession to the European Union resulted in the entry into force of the EU standards for the NRMM (Non-Road Mobile Machinery) vehicle category. On the basis of successive regulations of the European Parliament, newer and more stringent exhaust emission standards were introduced. Particular attention should be paid to the following standards: Stage IIIA (2006), Stage IIIB (2011) and Stage V (2019). Each of these stages divides the engines of off-road vehicles into categories depending on the power, type of ignition and the vehicle on which the engine is installed (Table 2). The standard provides for limits on such toxic compounds as $\mathrm{CO}, \mathrm{HC}, \mathrm{NO}_{\mathrm{x}}$, total $\mathrm{HC}$ and $\mathrm{NO}_{\mathrm{x}}$ emissions, as well as PM mass (Fig. 3).

Table 2. Railway vehicle engine categories in stages: IIIA, IIIB and V [4, 18]

\begin{tabular}{|c|c|c|c|}
\hline Norm & Stage IIIA & Stage IIIB & Stage V \\
\hline \multirow{3}{*}{$\begin{array}{l}\text { Types of } \\
\text { vehicles }\end{array}$} & $\begin{array}{c}\text { Railcars } \\
\text { RC A } \\
\mathrm{P}<130 \mathrm{~kW}\end{array}$ & $\begin{array}{c}\text { Railcars } \\
\quad \text { RC B } \\
\mathrm{P}<130 \mathrm{~kW}\end{array}$ & $\begin{array}{c}\text { Railcars } \\
\text { RLR, CI/SI; } \\
\text { P > } 0 \mathrm{~kW}\end{array}$ \\
\hline & $\begin{array}{c}\text { Locomotives } \\
\text { RL A }\end{array}$ & \multirow{2}{*}{$\begin{array}{l}\text { Locomotives } \\
\quad \mathrm{R} \\
\mathrm{P}>130 \mathrm{~kW}\end{array}$} & \multirow{2}{*}{$\begin{array}{c}\text { Locomotives } \\
\text { RLL, CI/SI } \\
\mathrm{P}>0 \mathrm{~kW}\end{array}$} \\
\hline & $\begin{array}{l}\text { Locomotives } \\
\text { RH A } \\
\mathrm{P}>560 \mathrm{~kW}\end{array}$ & & \\
\hline \multicolumn{4}{|c|}{ RC A - railcar engines, from 31.122005} \\
\hline \multicolumn{4}{|c|}{ RL A - locomotive engines, from 31.122006} \\
\hline \multicolumn{4}{|c|}{ RH - locomotive engines from 31.122008} \\
\hline \multicolumn{4}{|c|}{ RC B - railcar engines, from 31.1220011} \\
\hline \multicolumn{4}{|c|}{ - locomotive engines, from 31.1220011} \\
\hline RLR & \multicolumn{3}{|c|}{ - railway railcars, from 31.1220020} \\
\hline RLL -1 & \multicolumn{3}{|c|}{ - railway locomotives, from 31.1220020} \\
\hline
\end{tabular}

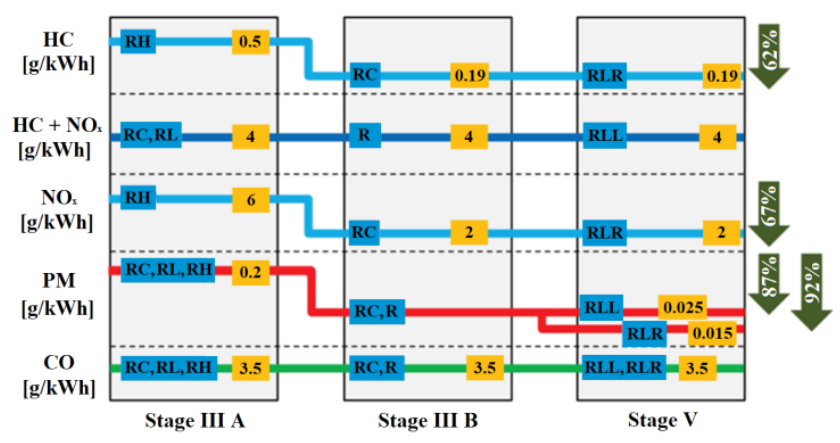

Fig. 3. Exhaust emission limits for Stages IIIA, IIIB and V [3]
As a result of these regulations, the latest designs of rail vehicle engines are equipped with modern solutions known mainly from passenger cars and trucks, such as the Common Rail injection system or the SCR (Selective Catalytic Reduction) reactor. With Stage $\mathrm{V}$, there is a requirement to test NRMM vehicles under real operating conditions. However, the limit values for the individual toxic exhaust gases have not yet been defined.

\section{Rail vehicle emission testing}

Emission tests for NRMM category vehicles are governed by ISO 8178 . The measurement cycles are carried out in the Stage I, II, IIIA, IIIB, IV and V standards for diesel engines with a net power of $19 \mathrm{~kW} \leq \mathrm{P} \leq 560 \mathrm{~kW}$, which run at constant or variable speed. The test procedure consists of a series of eleven measurements at different speed and torque values that characterize the typical operation of the vehicle engine. The different modes and their weighting factors are presented in Table 3. Weighting factor is the weight of the operating point for the calculation of the resulting emission. The test is performed under steady-state operating conditions, so it ignores transient conditions important from the emissivity point of the engine, when the drive unit has to adapt to the changing load.

Table 3 Test weight factors according to ISO 8178 [21]

\begin{tabular}{|c|c|c|c|c|c|c|c|}
\hline \multirow{2}{*}{$\begin{array}{l}\text { Phase } \\
\text { number }\end{array}$} & \multirow{2}{*}{$\begin{array}{c}\text { Torque } \\
{[\%]}\end{array}$} & \multirow{2}{*}{$\begin{array}{c}\text { Engine } \\
\text { speed } \\
{[\mathrm{rpm}]}\end{array}$} & \multicolumn{2}{|c|}{$\begin{array}{c}\text { Non-road } \\
\text { vehicles }\end{array}$} & \multicolumn{2}{|c|}{$\begin{array}{c}\text { Constant } \\
\text { engine speed }\end{array}$} & \multirow{2}{*}{$\begin{array}{c}\begin{array}{c}\text { Loco- } \\
\text { motives }\end{array} \\
\mathrm{F}\end{array}$} \\
\hline & & & $\mathrm{C} 1$ & $\mathrm{C} 2$ & D1 & D2 & \\
\hline 1 & 100 & \multirow{3}{*}{ Rated } & 0.15 & - & 0.30 & 0.05 & 0.25 \\
\hline 2 & 75 & & 0.15 & - & 0.50 & 0.25 & - \\
\hline 3 & 50 & & 0.15 & - & 0.20 & 0.30 & - \\
\hline 4 & 25 & \multirow{4}{*}{$\begin{array}{l}\text { Medium } \\
\text { range }\end{array}$} & & 0.06 & - & 0.30 & - \\
\hline 5 & 10 & & 0.10 & - & - & 0.10 & - \\
\hline 6 & 100 & & 0.10 & 0.02 & - & - & - \\
\hline 7 & 75 & & 0.10 & 0.05 & - & - & - \\
\hline 8 & 50 & \multirow{4}{*}{ Idle } & 0.10 & 0.32 & - & - & 0.15 \\
\hline 9 & 25 & & - & 0.30 & - & - & - \\
\hline 10 & 10 & & - & 0.10 & - & - & - \\
\hline 11 & 0 & & 0.15 & 0.15 & - & - & 0.60 \\
\hline \multicolumn{8}{|c|}{ C1 - test cycle for C.I. engines operated under intermittent speed } \\
\hline \multicolumn{8}{|c|}{ test cycle for S I enoines onerated with a nower $>20 \mathrm{~kW}$} \\
\hline \multicolumn{8}{|c|}{ 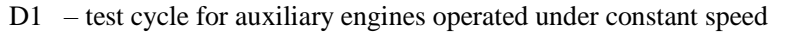 } \\
\hline \multicolumn{8}{|c|}{ - test cycle for C.I. engines operated under constant speed } \\
\hline $\mathrm{F}$ & cycle fo & ocomoti & s engi & & & & \\
\hline
\end{tabular}

Examination of exhaust gas composition is important in the context of engine diagnostics and its functional systems such as: catalytic converters, DPF filters (Diesel Particulate Filter) and SCR reactors [9]. Diagnostics of the wear of these elements in specific vehicles or entire series of engines may be an important step in the development of further technical solutions reducing the emission of toxic compounds. There are tests performed at the stage of research and development of structures and control tests, which are divided into:

- homologation (NTA - new type approval),

- conformity of production (tests of vehicles drawn randomly from series production to confirm compliance with approval),

_ periodic tests at motor vehicle diagnostic stations. 
Approval tests in accordance with ISO 8178 are a timeconsuming and complicated process. They are carried out in stationary conditions, often with the use of generator brakes. Control tests, performed after installing the engine on the vehicle, are carried out after an appropriate period of operation at a diagnostic station (Fig. 4) equipped with, among others, water resistor [3].

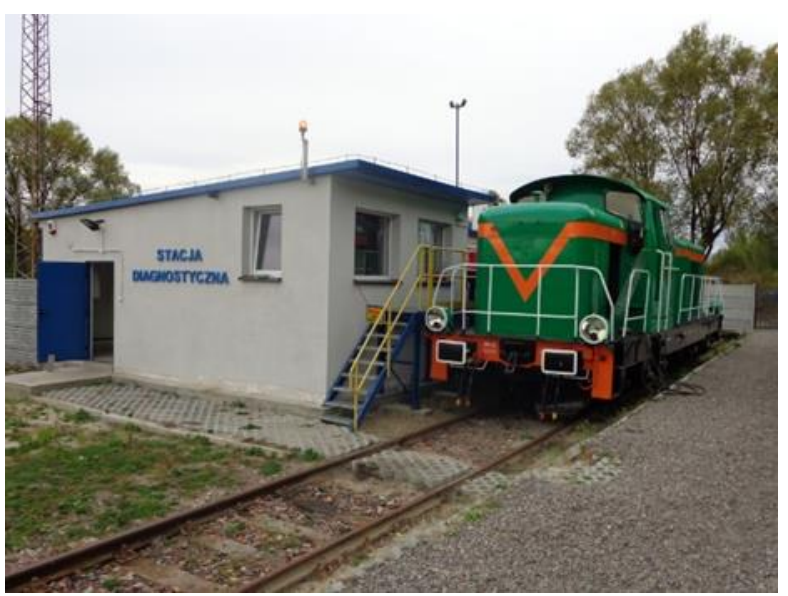

Fig. 4. Diagnostic station for measuring operational parameters and emissions of rail vehicles [20]

The concentrations of the individual exhaust components are measured by specific exhaust gas analyzers. The exhaust gases are supplied to them thanks to the use of a probe placed in the exhaust system. Engine operating parameters, including power, are regulated from the driver's cab. Testing emissions only under steady-state conditions leads to significant discrepancies between the results of the approval tests and the emissions under real conditions [2, $15,16]$. Hence the idea of a real driving test (RDE) for road vehicles. Such measurements have already been included in the WLTP (World harmonized Light-duty vehicles) Test Procedure tests. It is possible to develop a methodology of such tests for rail vehicles and to add their results to the test according to ISO 8178 thanks to the use of PEMS devices.

\section{The use of PEMS devices in the testing of the emissions of rail vehicles combustion engines}

The use of PEMS equipment allows for testing vehicle emissions in real engine operating conditions (Fig. 5). Devices of this type measure the concentrations of: $\mathrm{CO}, \mathrm{CO}_{2}$, $\mathrm{HC}, \mathrm{NO}_{\mathrm{x}}$ and the mass, number and size of solid particles. The engine operating parameters are taken from the CAN (Controller Area Network) bus. In order to facilitate the comparison of RDE test results with approval tests, the $\mathrm{CF}$ (Conformity Factor) has been introduced.[10]:

$$
\mathrm{CF}_{\mathrm{i}}=\frac{\mathrm{E}_{\mathrm{r}, \mathrm{i}}}{\mathrm{E}_{\mathrm{WHTC}, \mathrm{i}}}
$$

where: $\mathrm{i}$ - compounds for which the concordance factor is determined, $\mathrm{E}_{\mathrm{r}, \mathrm{i}}$ - emission under real operating conditions, $\mathrm{E}_{\mathrm{WHTC}, \mathrm{i}}$ - emission in the WHTC test.

Determining the maximum value of the $\mathrm{CF}$ coefficient makes it possible to take into account the difference between the operating conditions in RDE and type-approval tests and the tolerances of the devices used. Measurements with PEMS equipment can be particularly useful when comparing emissions before and after rolling stock upgrades. The assessment of the emission change and the determination of environmental benefits may be the basis for making a decision to carry out further modernization works. In addition, tests carried out in various conditions can be the basis for the assessment of emission tests and their compliance with the actual performance of vehicles.

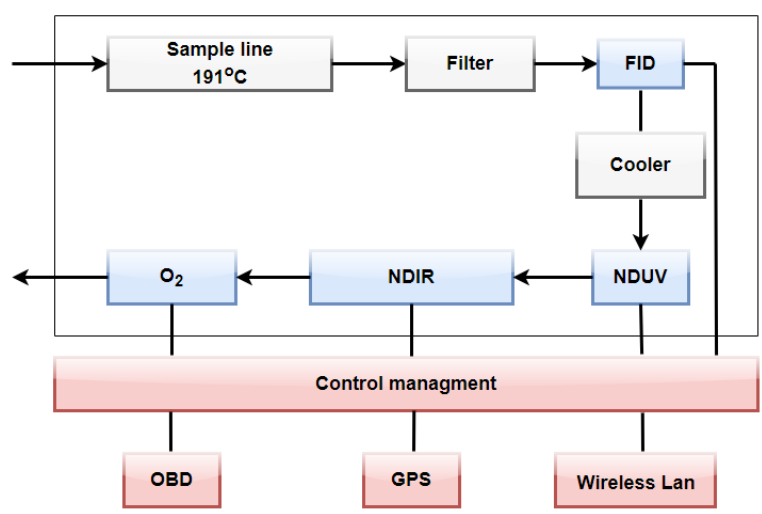

Fig. 5. Scheme of PEMS analyzer based on Semtech DS [12] FID (Flame Ionization Detector), NDUV (Non-dispersive Ultra Violet), NDIR (Nondispersive Infrared), OBD (On-Board Diagnostics), GPS (Global Positioning System), LAN (Local Area Network)

\section{Research on the emission of toxic compounds with use of remote-sensing technology}

Testing in laboratory conditions and PEMS measurements do not meet all the expectations of today's exhaust emission testing. Therefore, there was a need to develop methods that would allow the measurement of vehicle emissions at a reduced cost and time-consuming research. This possibility is provided by remote-sensing technology. They are currently used to assess the emissions of road vehicles. China and the USA are the leaders in work on such solutions. The Republic of China was the first country to introduce emission standards for measurements using this method.

Two development paths can be distinguished among the developed gate solutions [7]:

- open - path, based on absorption spectroscopy to study the concentrations of harmful compounds in the exhaust gas (Fig. 6a),

- extractive, where the exhaust gas sample is collected and analyzed by laboratory analyzers (Fig. 6a).

Both methods base their results on the relation of the concentrations of toxic compounds to the concentration of carbon dioxide in the exhaust gases. In most cases, the system measures nitrogen monoxide (NO), carbon monoxide $(\mathrm{CO})$, hydrocarbons $(\mathrm{HC})$ and carbon dioxide $\left(\mathrm{CO}_{2}\right)$. It is also possible to determine the concentrations of nitrogen dioxide $\left(\mathrm{NO}_{2}\right)$ and ammonia $\left(\mathrm{NH}_{3}\right)$. The measurement of particulate mass (PM) is possible indirectly from the exhaust blackness. Open - path uses the laws of optics and light absorption by exhaust gas components to determine their concentrations. So far, the results of the measurements are used to select vehicles with the highest emissivity, in order to refer them to further tests, e.g. PEMS. Determining the vehicle's emissivity on the basis of such measurements 
is easier for SI (Spark Ignition) engines than for CI (Compression Ignition) engines. The reason is the operation of diesel engines on lean mixtures with variable oxygen concentration. With properly operating SI engines, the $\mathrm{CO}_{2}$ concentration is usually around $15 \%$. In diesel engines, this value can vary from 1 to $13 \%$, and even $15 \%$ during regeneration of cleaning systems.

a)

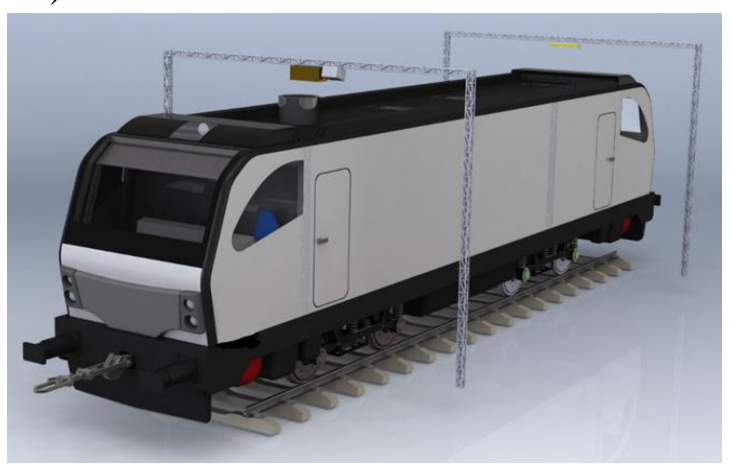

b)

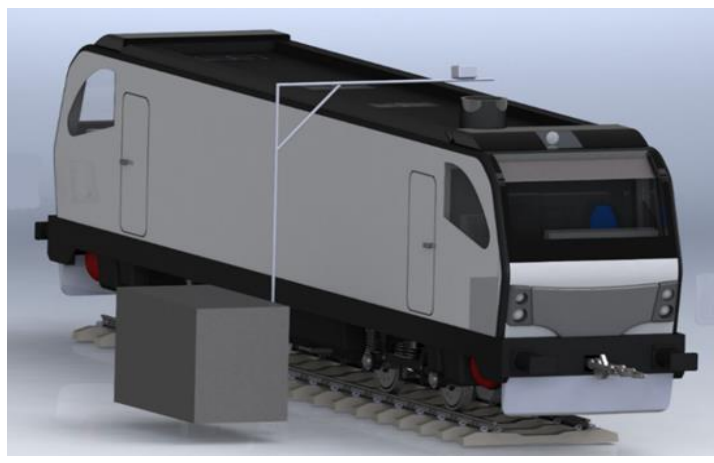

Fig. 6. Emission gate for the evaluation of type rail vehicles a) open path, b) extractive

The issue that constitutes the greatest difficulty in the wide application of remote-sensing technology is the difficulty in unambiguously comparing their results with the

maximum emission values introduced by the standards. The remote-sensing technology does not allow the measurement of the exhaust gas intensity, so it is impossible to determine the road $[\mathrm{g} / \mathrm{km}$ ] or specific emission $[\mathrm{g} / \mathrm{kWh}]$. Road emissions relate the mass of the pollutant to the distance traveled by the vehicle, while the specific emission relates to the useful work performed by the vehicle engine. To improve the information carrying capacity of the results, three methods of comparing the results to the maximum values were proposed. The first one is based on the estimation of $\mathrm{CO}_{2}$ concentration on the basis of dynamic properties and characteristics. The second method is to test the amount of oxygen versus carbon dioxide in the exhaust cloud close to the end of the exhaust system. Unfortunately, there is no technology yet that would allow such measurements to be made. The third way is to define emission factors based on $\mathrm{CO}_{2}$ emissions or fuel consumption. The assessment of the toxicity indicators, which refer individual compounds to $\mathrm{CO}_{2}$ emissions, is presented in [17]. This approach seems to be the most developmental at present. A method of converting the concentrations of toxic compounds into road emissions has been developed, while maintaining certain dependencies.

\section{Examples of tests in real operating conditions}

The tests in real operating conditions were carried out on an unloaded T448.P diesel locomotive (Fig. 7, Table 4).

Table 4. Basic technical data of the research object (according to the operation and maintenance documentation [5])

\begin{tabular}{|l|c|}
\hline Type of work & four-stroke cycle \\
\hline Injection & direct \\
\hline Top-up & turbocharging \\
\hline Layout & $\mathrm{V} 90^{\circ}$ \\
\hline Cylinder liner diameter $[\mathrm{mm}]$ & 165 \\
\hline Piston stroke $[\mathrm{mm}]$ & 185 \\
\hline Number of cylinders & 12 \\
\hline Displacement volume $\left[\mathrm{dm}^{3}\right]$ & 47.5 \\
\hline Compression ratio & $13.6: 1$ \\
\hline Maximum power $[\mathrm{kW}]$ & 680 \\
at rotational speed $[\mathrm{rpm}]$ & 1300 \\
\hline Torque at $40^{\circ} \mathrm{C}$ coolant temperature $[\mathrm{Nm}]$ & 560 \\
\hline
\end{tabular}
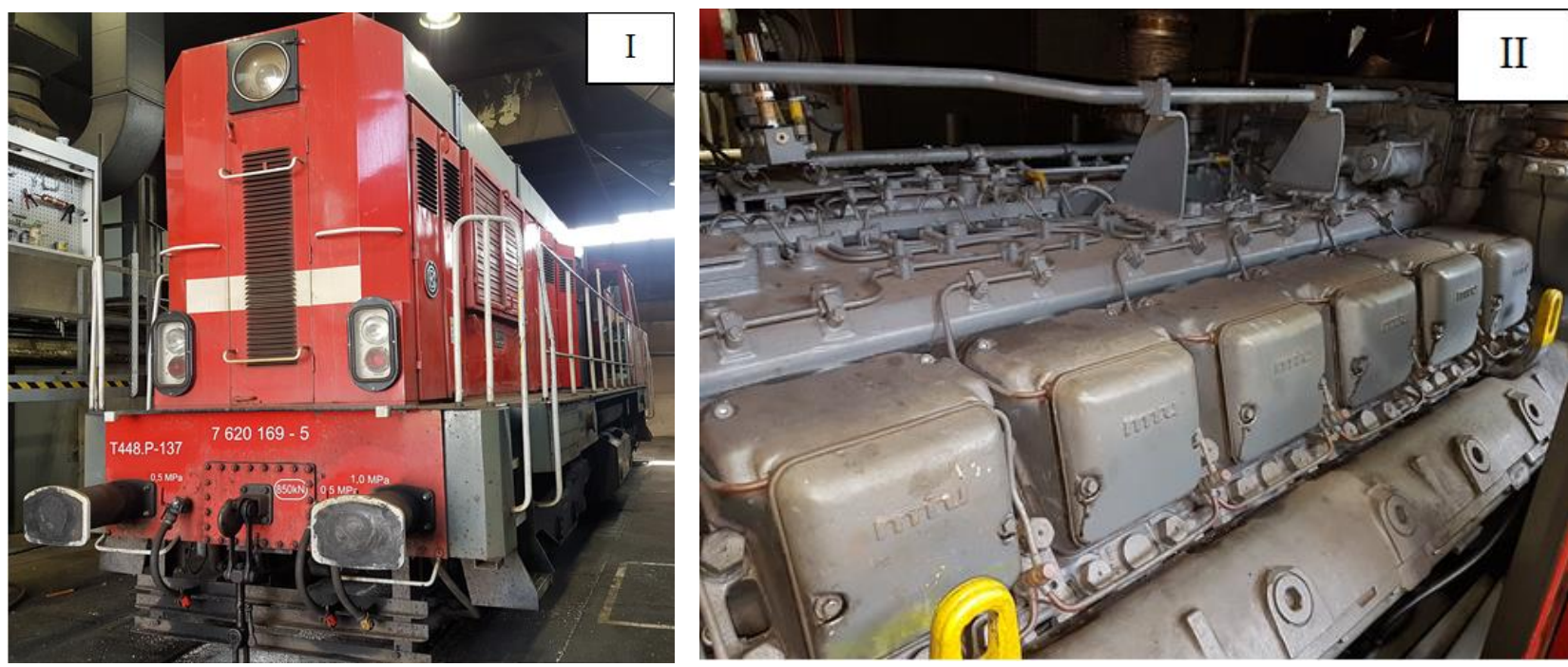

Fig. 7. General view: I - diesel locomotive T448, II - diesel engine 12 V396 
The aim of the measurements was to assess the emission of toxic compounds, taking into account the histograms of the load of locomotives under typical operating conditions in the light of the requirements of the relevant standards, directives and regulations $[4,6,8,18]$. The locomotive was equipped with a 12-cylinder combustion engine with a displacement of $47.5 \mathrm{dm}^{3}$. It had a maximum power of 680 $\mathrm{kW}$ at a rotational speed of 1,300 rpm. The diagram of the performed measurements is shown in Fig. 8.

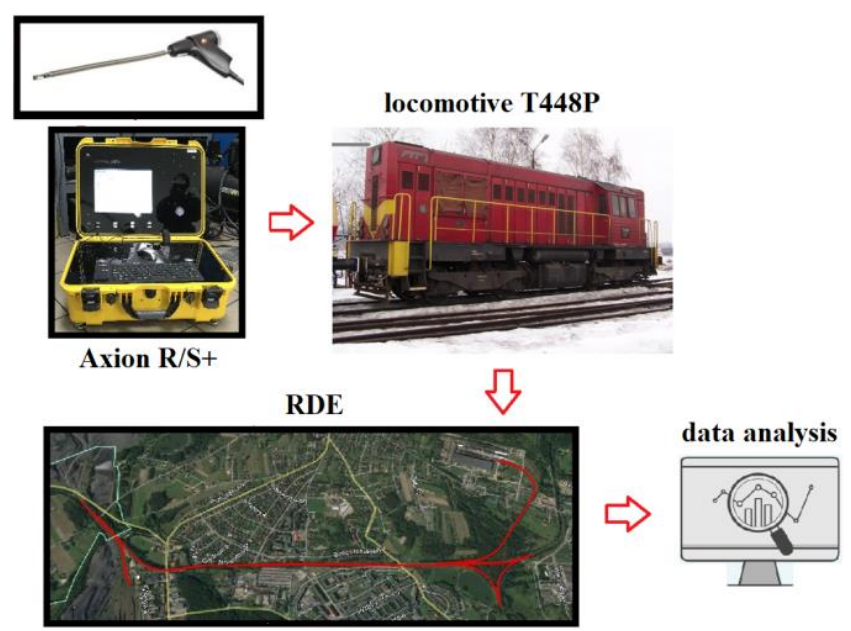

Fig. 8. Diagram of the performed tests

The tests were carried out using the Micro PEMS Axion $\mathrm{R} / \mathrm{S}+$ mobile analyzer manufactured by Global MRV. The device measures the concentration of gaseous toxic compounds with the use of: a non-dispersive infrared analyzer NDIR $\left(\mathrm{CO}_{2}, \mathrm{CO}, \mathrm{HC}\right)$ and an electrochemical analyzer (NO). The equipment also allows you to measure PM concentration using a method based on Laser Scatter, in which the speed of particle movement is measured (taking into account the values assigned to PM10).

Based on the recorded parameters during the tests, the characteristics of the time density as a function of velocity - acceleration (V-a) were determined (Fig. 9). The area defined by the ranges $\left(0 \mathrm{~m} / \mathrm{s} ; 8 \mathrm{~m} / \mathrm{s}>\right.$ and $\left(-0.5 \mathrm{~m} / \mathrm{s}^{2} ; 0.5\right.$ $\mathrm{m} / \mathrm{s}^{2}>$ ) had the highest share of working time $-68 \%$. The highest values for a single operating point $(17.5 \%)$ were obtained while for speed $(4 \mathrm{~m} / \mathrm{s} ; 6 \mathrm{~m} / \mathrm{s}>$ and acceleration $0 \mathrm{~m} / \mathrm{s}^{2}$ and for idling $(17.4 \%)$. It is also worth noting that the share of operating time from a run by a locomotive with zero acceleration was $61 \%$. was $4.5 \mathrm{~km}$ with an average speed of $14.5 \mathrm{~km} / \mathrm{h}$, the locomotive during this test achieved a maximum speed of $54 \mathrm{~km} / \mathrm{h}$.

The intensity of $\mathrm{CO}_{2}$ emissions (Fig. 10) of the tested object is closely related to the speed and acceleration of the vehicle, which can be seen in the entire range of vehicle operation. It is closely related to the fuel consumption of the locomotive. The highest emission intensity occurred in the following ranges $\left(14 \mathrm{~m} / \mathrm{s} ; 16 \mathrm{~m} / \mathrm{s}>\mathrm{i}\left(0 \mathrm{~m} / \mathrm{s}^{2} ; 0.5 \mathrm{~m} / \mathrm{s}^{2}>\right.\right.$ $(117 \mathrm{~g} / \mathrm{s})$ and $\left(12 \mathrm{~m} / \mathrm{s} ; 14 \mathrm{~m} / \mathrm{s}>\right.$ and $\left(0 \mathrm{~m} / \mathrm{s}^{2} ; 0.5 \mathrm{~m} / \mathrm{s}^{2}>(115\right.$ $\mathrm{g} / \mathrm{s})$. The average emission intensity remained at $34 \mathrm{~g} / \mathrm{s}$. The area with the highest values is described by the speed ranges $(6 \mathrm{~m} / \mathrm{s} ; 16 \mathrm{~m} / \mathrm{s})$. > and acceleration $\left(0 \mathrm{~m} / \mathrm{s}^{2} ; 1 \mathrm{~m} / \mathrm{s}^{2}>\right.$. While idling, the vehicle emitted $17.4 \mathrm{~g} / \mathrm{s} \mathrm{CO}_{2}$.

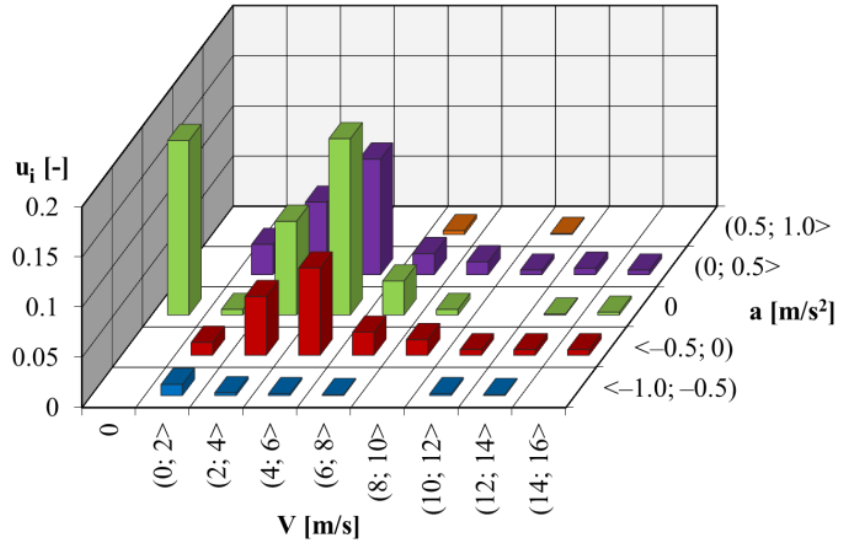

Fig. 9. Operating time density graph in real operating conditions expressed in speed and acceleration intervals

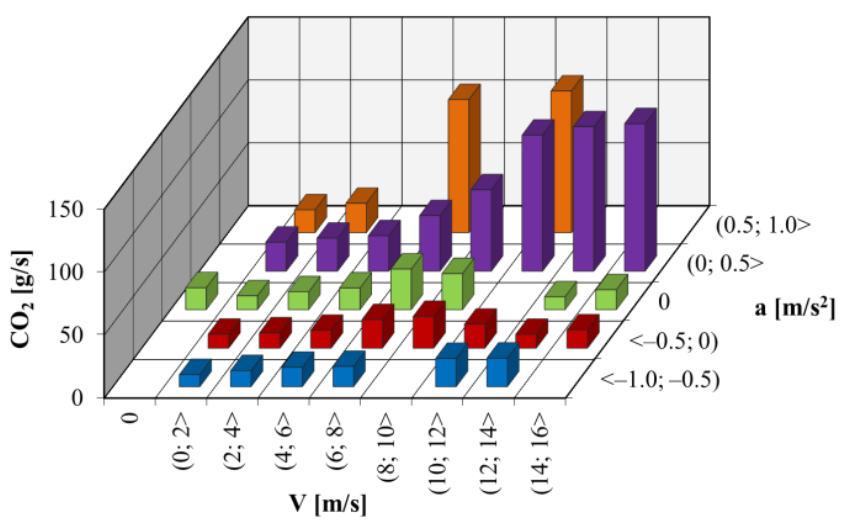

Fig. 10. $\mathrm{CO}_{2}$ exhaust emission intensity of the tested vehicle in speed and acceleration intervals

As in the case of carbon dioxide, the obtained $\mathrm{CO}$ values depended on the speed and acceleration of the vehicle, but in this case their distribution was more even (Fig. 11). The highest values were obtained for the area of $(6 \mathrm{~m} / \mathrm{s} ; 16$ $\mathrm{m} / \mathrm{s}>$ and $\left(0 \mathrm{~m} / \mathrm{s}^{2} ; 1 \mathrm{~m} / \mathrm{s}^{2}>\right)$, with the maximum value for a single operating point $\left(6 \mathrm{~m} / \mathrm{s} ; 8 \mathrm{~m} / \mathrm{s}>\right.$ and $\left(0.5 \mathrm{~m} / \mathrm{s}^{2} ; 1 \mathrm{~m} / \mathrm{s}^{2}>\right.$ was $2.44 \mathrm{~g} / \mathrm{s}$. The average value of carbon monoxide for the entire test was $0.56 \mathrm{~g} / \mathrm{s}$. At the point characterized by the lack of speed and acceleration, the vehicle was characterized by a value of $0.39 \mathrm{~g} / \mathrm{s}$.

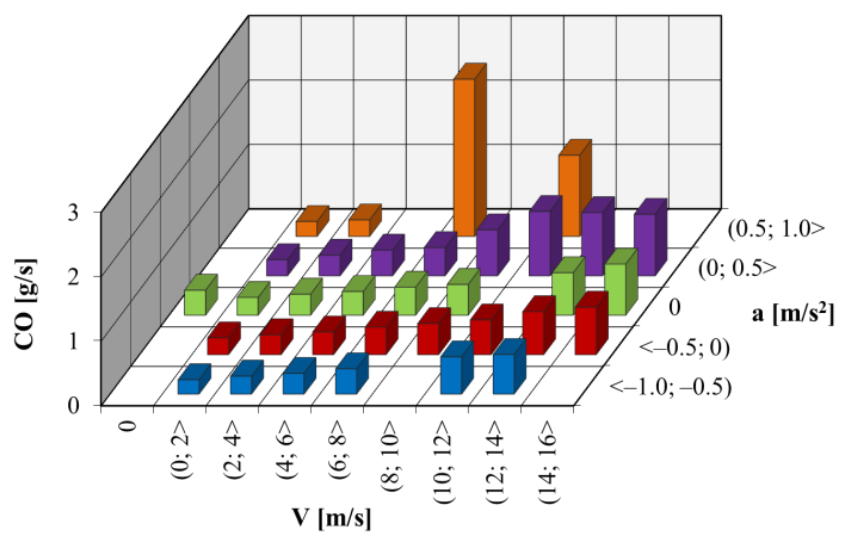

Fig. 11. CO exhaust emission intensity of the tested vehicle in speed and acceleration intervals 
The values of $\mathrm{HC}$ emission intensity increased with increasing vehicle speed, and its average value was equal to $0.06 \mathrm{~g} / \mathrm{s}$. The highest values occurred in the area $(10 \mathrm{~m} / \mathrm{s}$; $16 \mathrm{~m} / \mathrm{s}>$ for the entire vehicle acceleration range. A single operating point characterized by the maximum value $(0.1$ $\mathrm{g} / \mathrm{s})$ occurred at the speed $(14 \mathrm{~m} / \mathrm{s} ; 16 \mathrm{~m} / \mathrm{s}>$ and acceleration $\left(0 \mathrm{~m} / \mathrm{s}^{2} ; 0.5 \mathrm{~m} / \mathrm{s}^{2}>\right.$. For idling the obtained value was close to the average value from the whole test.

The presented characteristics of the $\mathrm{NO}_{\mathrm{x}}$ emission intensity (Fig. 13) showed that the highest values occurred in the following ranges $\left(6 \mathrm{~m} / \mathrm{s} ; 16 \mathrm{~m} / \mathrm{s}>\right.$ and $\left(0 \mathrm{~m} / \mathrm{s}^{2} ; 1 \mathrm{~m} / \mathrm{s}^{2}>\right.$, where the maximum value was $2.84 \mathrm{~g} / \mathrm{s}$ ) was obtained at the operating point determined by the intervals $(14 \mathrm{~m} / \mathrm{s} ; 16$ $\mathrm{m} / \mathrm{s}>$ and $\left(0 \mathrm{~m} / \mathrm{s}^{2} ; 0.5 \mathrm{~m} / \mathrm{s}^{2}>\right.$. The average value obtained during the tests was $0.6 \mathrm{~g} / \mathrm{s}$. For the point $0 \mathrm{~m} / \mathrm{s}$ and $0 \mathrm{~m} / \mathrm{s}^{2}$, the emission rate was below $0.2 \mathrm{~g} / \mathrm{s}$.

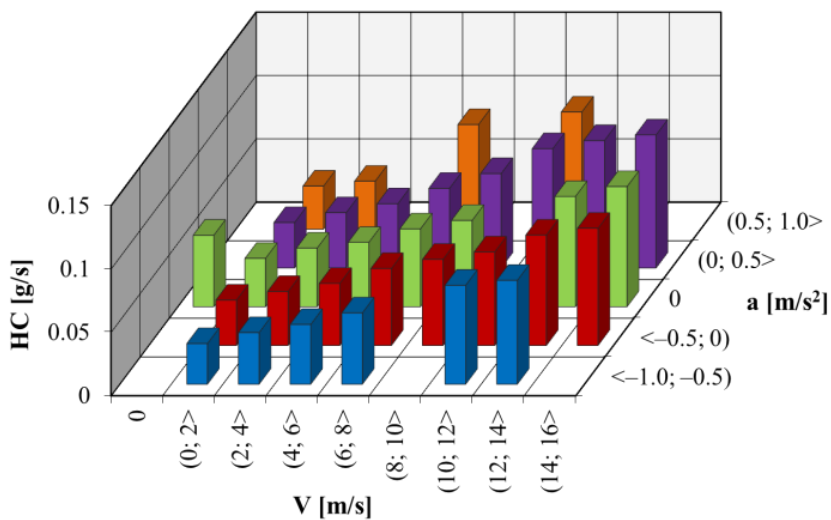

Fig. 12. HC exhaust emission intensity of the tested vehicle in speed and acceleration intervals

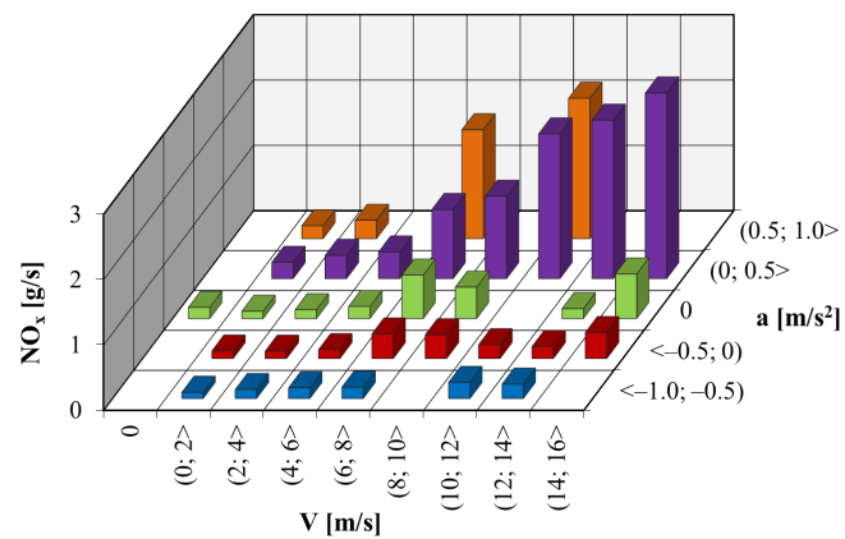

Fig. 13. $\mathrm{NO}_{\mathrm{x}}$ exhaust emission intensity of the tested vehicle in speed and acceleration intervals

As in the case of $\mathrm{NO}_{\mathrm{x}}$, the PM emission intensity (Fig. 14) showed that the highest values occurred in the ranges $\left(6 \mathrm{~m} / \mathrm{s} ; 16 \mathrm{~m} / \mathrm{s}>\right.$ and $\left(0 \mathrm{~m} / \mathrm{s}^{2} ; 1 \mathrm{~m} / \mathrm{s}^{2}>\right.$. Maximum value $0.34) \mathrm{g} / \mathrm{s}$ was obtained at a single operating point characterized by the speed ranges $(6 \mathrm{~m} / \mathrm{s} ; 8 \mathrm{~m} / \mathrm{s}>$ and acceleration $\left(0.5 \mathrm{~m} / \mathrm{s}^{2} ; 1 \mathrm{~m} / \mathrm{s}^{2}>\right)$. The average value of the PM emission rate was $0.04 \mathrm{~g} / \mathrm{s}$, while the value for idling did not exceed $0.01 \mathrm{~g} / \mathrm{s}$.

The next stage of the research was the measurements of the specific exhaust emissions of the tested object and comparing them with the exhaust emission standards applicable in the years of its production, included in the ORE B13 Rp 22 report, introduced in 1991. During the measurements, the locomotive obtained the specific emission of carbon monoxide at the level of $7.8 \mathrm{~g} / \mathrm{kWh}$. It was the only compound that did not meet the limits $(4.0 \mathrm{~g} / \mathrm{kWh})$ established in the standard. On the other hand, the locomotive met the requirements for $\mathrm{HC}$ and $\mathrm{NO}_{x}$, their values were respectively $1.12 \mathrm{~g} / \mathrm{kWh}$ and $8.4 \mathrm{~g} / \mathrm{kWh}$. Tthe limit values were 1.6 $\mathrm{g} / \mathrm{kWh}$ for hydrocarbon and $16 \mathrm{~g} / \mathrm{kWh}$ for nitrogen oxides. However, the report did not specify any particulate limits. The favorable results result from the fact that the engine of the tested object was modernized in 1995 in order to improve its ecological indicators.

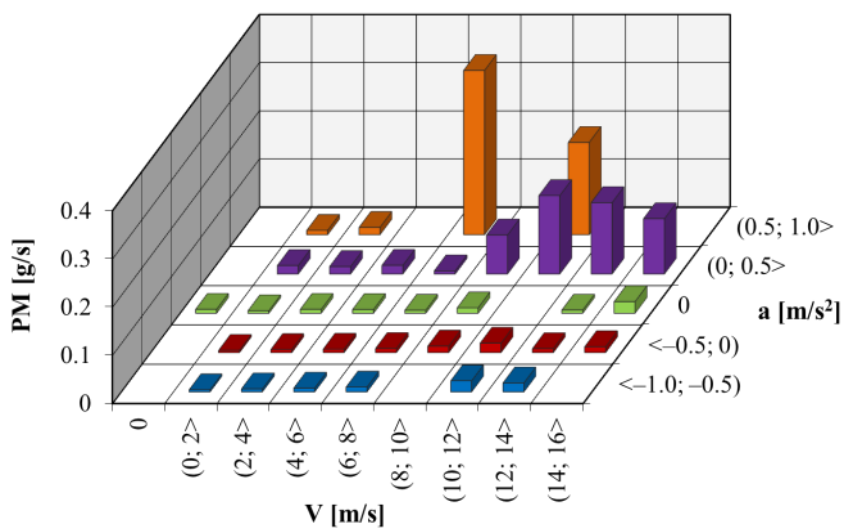

Fig. 14. PM exhaust emission intensity of the tested vehicle in speed and acceleration intervals

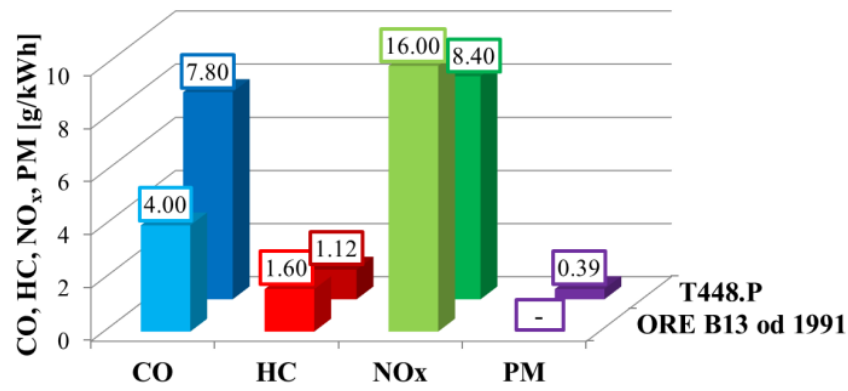

Fig. 15. Summary of test results with the limit values of harmful exhaust compounds according to ORE B13 Rp 22 in force since 1991

\section{Summary}

The number of diesel rail vehicles operated in Poland, their share in the rolling stock and planned investments indicate that non-electrified rolling stock will still constitute a significant part of rail vehicles in Poland. Successive exhaust emission standards for rail vehicles reduce the maximum specific emissions of toxic compounds. Tests on the emission of toxic compounds from rail vehicle engines should evolve towards combining stationary tests and measurements in real operating conditions.

The presented example of testing a rail vehicle during real operation proves that it is possible to learn more about the operating conditions of locomotives and their influence on ecological indicators. The test object had an engine in good technical condition (after renovation), thanks to which the obtained specific emission results indicate that it meets the limit according to which it was approved in addition to CO. In addition, it is not possible to emit PM as the ORE 
B13 standard did not define a value for this toxic compound.

The use of PEMS equipment makes it possible to measure emissions during the normal operation of rolling stock taking into account the limitations related to the gauge and safety. However, the introduction of the conformity factor CF may allow effective use of tests under real engine operating conditions and comparison of their results with the maximum values specified by EU standards. It should also be expected that remote sensing solutions for measuring rail vehicles will allow to identify the most environmentally harmful vehicles for further research.

\section{Acknowledgements}

The research was funded by European Union from European Regional Development Fund through the National Centre for Research and Development (Narodowe Centrum Badań i Rozwoju) - research project within the Smart Growth Programme (contract No. POIR.04.01.02-000002/18).

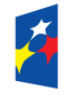
European Funds Smart Growth
European Union European Regional
Development Fund
Republic of Poland

\section{Nomenclature}

CAN controller area network

$\mathrm{CF}$ conformity factor

CI compression ignition

$\mathrm{CO}$ carbon monoxide

$\mathrm{CO}_{2}$ carbon dioxide

DPF diesel particulate filter

FID flame ionization detector

GPS global positioning system

$\mathrm{HC}$ hydrocarbons

ISO international organization for standardization

LAN local area network

NDIR non-dispersive infrared
NDUV non-dispersive ultra violet

$\mathrm{NO}_{\mathrm{x}} \quad$ nitrogen oxides

NTA new type approval

OBD on-board diagnostics

ORE centre for education development

PEMS portable emissions measurement systems

PM particulate matter

RDE real driving emissions

SCR selective catalytic reduction

SI spark ignition

WLTP world harmonized light-duty vehicles

\section{Bibliography}

[1] ANDRZEJEWSKI, M., DASZKIEWICZ, P., RYMANIAK, Ł. et al. Impact of modernization of locomotives operated in Poland on the emission of toxic compounds in exhaust gases. Autobusy: Technika, Eksploatacja, Systemy transportowe. 2018, 19(12), 54-57.

https://doi.org/10.24136/atest.2018.353

[2] ANDRZEJEWSKI, M., FUĆ, P., GALLAS, D. et al. Impact of driving style on the exhaust emission of a diesel multiple unit. 17th International Conference on Railway Engineering Design \& Operation (COMPRAIL 2020), 365-376.

https://doi.org/10.2495/CR200341

[3] ANDRZEJEWSKI, M., PIELECHA, I., MERKISZ, J. et al. Legal conditions in the aspect of pollutant emissions from exhaust systems of rail vehicles engines. Journal of KONES. 2018, 25(1), 257-264.

https://doi.org/10.5604/01.3001.0012.2475

[4] Directive 2004/ 26/EC of the European Parliament and of the Council of 21 April 2004 amending Directive 97/68/EC on the approximation of the laws of the Member States relating to measures against the emission of gaseous and particulate pollutants from internal combustion engines to be installed in non-road mobile machinery.

https://eur-lex.europa.eu/legal-

content/EN/TXT/?uri=celex\%3A32004L0026

[5] Dokumentacja techniczno-rozruchowa zmodernizowanej lokomotywy spalinowej Typu T448.P TOM II.

http://www.katalogkolejowy.pl/produkty_det/3899

[6] Dyrektywa Komisji 2010/26/UE z dnia 31 marca 2010 r. zmieniająca dyrektywę 97/68/WE Parlamentu Europejskiego i Rady w sprawie zbliżenia ustawodawstw państw członkowskich odnoszących się do środków dotyczących ograniczenia emisji zanieczyszczeń gazowych i pyłowych z silników spalinowych montowanych w maszynach samojezdnych nieporuszających się po drogach. https://eur-lex.europa.eu/legalcontent/PL/TXT/?uri=CELEX\%3A32010L0026

[7] ICCT. Technical considerations for choosing a metric for vehicle remote-sensing regulations. November 2019. https://theicct.org/publications/china-vehicle-remotesensing-regulations

[8] ISO/DIS 8178-1.2, 1995. Reciprocating internal combustion engines - exhaust emission measurement - Part 1: Test-bed measurement of gaseous and particulate exhaust emissions. https://www.iso.org/standard/15268.html

[9] LEWANDOWSKI, M. Silniki spalinowe pojazdów szynowych. WKŁ, Warszawa 2018.

[10] LIJEWSKI, P., MERKISZ, J., PIELECHA, J. PEMS-based investigations into exhaust emissions from non-road and rail vehicles. Combustion Engines. 2016, 166(3), 46-53. https://doi.org/10.19206/CE-2016-339

[11] Mały Rocznik Statystyczny Polski. Warszawa 2004.

[12] Mały Rocznik Statystyczny Polski. Warszawa 2009.

[13] Mały Rocznik Statystyczny Polski. Warszawa 2014.

[14] Mały Rocznik Statystyczny Polski. Warszawa 2019.

[15] MERKISZ, J., LIJEWSKI, P., FUĆ, P. et al. Exhaust emission tests from non-road vehicles conducted with the use of PEMS analyzers. Eksploatacja i Niezawodność - Maintenance and Reliability. 2013, 15(4), 364-368.

[16] MERKISZ, J., PIELECHA, I., ANDRZEJEWSKI, M. et al. Legal conditions in the aspect of pollutant emissions from exhaust systems of rail vehicles engines. Journal of KONES. 2018, 25(1), 257-264. https://doi.org/10.5604/01.3001.0012.2475

[17] MERKISZ, J., RYMANIAK, Ł., LIJEWSKI, P. et al. Tests of ecological indicators of two-way vehicles meeting Stage IIIB and Stage IV standards in real operating conditions. Rail Vehicles/Pojazdy Szynowe. 2020, 1, 1-9. https://doi.org/10.53502/RAIL-138495 
[18] Regulation (EU) 2016/1628 of the European Parliament and of the Council of 14 September 2016 on requirements relating to gaseous and particulate pollutant emission limits and type-approval for internal combustion engines for non-road mobile machinery, amending Regulations (EU) No 1024/2012 and (EU) No 167/2013, and amending and repealing Directive 97/68/EC (Text with EEA relevance). https://eur-lex.europa.eu/legalcontent/EN/TXT/?uri=CELEX\%3A32016R1628

Michalina Kamińska, MEng. - Faculty of Civil and Transport Engineering, Poznan University of Technology.

e-mail: michalina.kaminska@put.poznan.pl

Daniel Kołodziejek, MEng. - Faculty of Civil and Transport Engineering, Poznan University of Technology.

e-mail: daniel.kolodziejek@student.put.poznan.pl
[19] Urząd transportu kolejowego. Tabor kolejowy przewoźników towarowych - stan obecny i plany do 2023 r. 2018.

[20] ASCO RAIL sp. z o.o. https://www.ascorail.pl (accessed on 05.2021)

[21] DieselNet. Engine \& emission technology online - since 1997. https://dieselnet.com (accessed on 05.2021)

Natalia Szymlet, MEng. - Faculty of Civil and Transport Engineering, Poznan University of Technology.

e-mail: natalia.r.szymlet@doctorate.put.poznan.pl

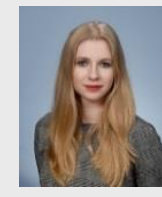

Prof. Paweł Fuć, DSc., DEng. - Faculty of Civil and Transport Engineering, Poznan University of Technology.

e-mail:pawel.fuc@put.poznan.pl

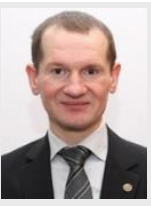

Rafał Grzeszczyk, DEng. - ODIUT Automex sp. z o.o., WSB Gdańsk.

e-mail: rafal.grzeszczyk@automex.eu 